\title{
Needs-based syllabus design for students of English in Hungarian technical universities
}

\section{Csilla Sárdi}

\section{(2) OpenEdition}

1 Journals

\section{Electronic version}

URL: http://journals.openedition.org/asp/3168

DOI: $10.4000 / a s p .3168$

ISSN: 2108-6354

\section{Publisher}

Groupe d'étude et de recherche en anglais de spécialité

\section{Printed version}

Date of publication: 1 December 1997

Number of pages: 285-304

ISSN: 1246-8185

\section{Electronic reference}

Csilla Sárdi, « Needs-based syllabus design for students of English in Hungarian technical

universities », ASp [Online], 15-18| 1997, Online since 13 November 2012, connection on 10 December 2020. URL : http://journals.openedition.org/asp/3168 ; DOI : https://doi.org/10.4000/asp.3168

This text was automatically generated on 10 December 2020.

Tous droits réservés 


\title{
Needs-based syllabus design for students of English in Hungarian technical universities
}

\author{
Csilla Sárdi
}

\section{Introduction}

1 This paper ${ }^{1}$ investigates issues of needs-based language course design. In particular, it focuses on the question of how to integrate learners' language needs, identified with the help of a needs survey, into syllabus content. This will be achieved through attempting to translate the results of a needs analysis, which investigated the English language needs of students in Hungarian Technical Universities, into syllabus design.

2 The paper is divided into four sections. Section One provides a theoretical framework for needs-based course design (and within this syllabus design), and highlights the issues on which the paper focuses. Section Two provides the context of the syllabus design by outlining the research project of which the syllabus design formed part. Section Three shows how the syllabus of the needs based course was designed, and Section Four provides insights in relation to the limitations of the proposed syllabus.

\section{Theoretical framework}

3 Although the importance of needs analysis in terms of course design has been repeatedly emphasised (Dubin \& Olstain 1986; Hutchinson \& Waters 1987; Munby 1978; Richterich 1973/1980; Robinson 1991; West 1994) the professional literature appears to treat needs analysis and course design as separate issues (e.g.Munby 1978; Teemant et al. 1993). As a consequence, little work has been done on creating a link between the two areas (Brindley 1989). A possible reason for this is that the task of linking needs analysis and course design is more complex than it may seem. The task is complex because it requires 
a systematic approach whereby needs analysis is developed within the framework of course design and in concert with the theoretical assumptions which underlie course design. different conclusions depending on their views on language, learning and teaching. It can also mean, however, that needs analysis findings will be abandoned during course design. This is why it is important to establish a sound theoretical framework for course design in which the results of needs analysis will be incorporated. Thus, it is essential that the principles arising from the designer's approach to course design are in concert with the needs analysis procedures (Coffey 1984; Littlewood 1992b; Munby 1978; Richterich 1973/1980). In this sense, the design of the needs analysis is subordinate to and informed by the previously established theoretical framework for course design. For example, in the case of a language-centred course the needs analysis will concentrate on categories of language which are in correspondence with the views the analysts have of the nature of language (Coffey 1984; Munby 1978; Tarone 1991). It is equally possible, however, to take a broader approach to course design and take into account processes involved in learning (Jacobson 1986), teaching and learning strategies (Allwright 1982; Widdowson 1981) as well as the means available in the learning situation (Crocker 1981; Holliday 1994).

7 There have been many attempts to differentiate between needs types, and there has been a wide acceptance of the view that 'needs' is an umbrella term (Hutchinson \& Waters 1987; Mackay \& Bosquet 1981; McDonough 1984; Porcher 1983; Richterich 1983; Robinson 1991; West 1994). Such a conceptualisation of needs underpins the view that the type of needs analysis applied by any analyst will depend on his/her understanding of what is meant by 'needs'. It also stresses the importance of a clear, working definition of needs for investigation purposes.

8 A useful classification of needs is offered by Hutchinson and Waters (1987:55-62). They differentiate between two needs groups: (1) target needs (i.e.what the learner needs to do in the target situation) and (2) learning needs (i.e. how the learner can acquire the language needed in such situations). These are further divided into sub-categories. Thus, necessities, lacks and wants belong to target needs, whereas learning strategies and constraints are part of learning needs (for a detailed discussion on needs these types see ibid.).

The second issue which needs to be mentioned here is how to integrate needs analysis findings into course design. Berwick (1989) points out that, in general, three types of responses are possible to identified needs : "ignoring them", "interpreting them" and 
"applying them directly" (op. cit.: 55). He also notes that the most usual response is some kind of interpretation by the expert.

The third important issue in terms of integrating needs analysis findings into course design is that needs may conflict. Conflicts can arise between different parties involved in the needs analysis in relation to a number of stages of the teaching and learning process (Robinson 1991: 8). Normally, there are three parties (i.e. the teacher, the learners and the company) involved in an ESP situation (Johns \& Dudley-Evans 1980; West 1994), whereas it is the teacher's and the learners' needs that can be taken into account in the case of General English courses. It is also possible to turn to other sources of information, for example to former students and to people working in the target situation (Allen \& Spada 1983; Richterich 1973/1980). Jones (1991) notes that the differing needs of these parties may result in constraint. It is therefore crucial for the designer to decide whose needs to give priority to when using the results of needs analysis for course design purposes.

What follows is an attempt to show how the issues raised in this section were dealt with when proposing a syllabus based on the English language needs of Technical University students. Before doing that, however, it is necessary to include a brief outline of the research project within which the development of the syllabus took place in order to understand the context of our syllabus design.

\section{Context}

The starting point of the research project was the hypothesis that there was a discrepancy between (1) the objectives and outcomes of existing EFL courses in Hungarian Technical Universities, and (2) the English language needs of the EFL students as defined by: the requirements of the labour market, the academic environment and situations occurring in students' everyday life.

The research focused on Technical Universities which offered three- and four- year courses (mûszaki foiskola). ${ }^{2}$ In 1996, an analysis was carried out into students' English language needs, and it had two aims. One was to test the above hypothesis. The other was to provide a basis for the design of a needs-based English language course (and within this a needs-based syllabus).

14 Four target groups were involved in the investigation: (1) students who majored in technical subjects and learned English as part of their course requirements in Hungarian Technical Universities, (2) their EFL teachers within the universities, (3) subject lecturers teaching technical subjects to the students, and (4) representatives of companies all over Hungary.

The analysis confirmed the hypothesis and showed that there was a discrepancy, in many respects, between the present teaching and learning situation and the students' needs. These are summarised below:

1. Students felt that they needed more focus on vocational and academic English than was provided during language instruction.

17 2. Students wanted to concentrate on grammar, translation, speaking and understanding more than EFL teachers felt it necessary. They also felt that less time should have been devoted to reading and writing. 
18 3. A strong discrepancy was found between students' and EFL teachers' perception regarding the usefulness of different classroom activities. All in all, students seemed to rely on traditional methods more than teachers did, although some modern methods (e.g. problem solving, role, play) were more popular with students.

19 4. Students' level of English language proficiency was not sufficient to fulfil the employers' requirements in work situations.

5. EFL teachers assumed that students would use English more often for general purposes whereas students thought the opposite.

6. Students appeared willing to use English for academic purposes more often than was required by subject lecturers and was expected by EFL teachers.

7. Employees needed English frequently for various purposes within the vocational domain and it was evident that such uses were not given the focus they deserved in EFL courses in Hungarian Technical Universities.

It is beyond the purposes of the present paper to discuss the discrepancies in detail (for a more detailed account see Sárdi 1996, 1998).

The needs survey also made it possible to identify learners' needs which were then translated into course design. In particular, a syllabus and a methodological framework were proposed. In Section Three, an attempt is made to show how needs were translated into syllabus design. Focused attention will be given to the issues raised in Section One.

\section{Designing a needs-based syllabus}

The following issues were highlighted in Section One:

1. It is essential to provide a clear working definition of needs which is based on the theoretical assumptions underlying course design.

2. It is also essential to decide what to do with the identified needs (i.e. ignore, interpret or adopt them).

3. Furthermore, it is important to decide whose needs take priority when needs of different target groups conflict.

We discuss below how these issues were respectively taken into account when designing the syllabus of our needs-based English language course.

\section{Working definition of needs}

30 Although recent approaches to syllabus design (e.g. Prahbu 1987, Breen 1984, Long 1985, Long and Crookes 1992) emphasise the importance of the learning process, and therefore, cross the line between syllabus and methodology, I would argue that it is by no means the role of the syllabus to determine how language learning should be achieved. Instead, the role of the syllabus is to provide guidelines in terms of what the language instruction aims to achieve. In other words, its role is to specify content. ${ }^{3}$

31 If we accept the above statement it follows that needs which are intended to be included in the syllabus should be conceptualised along the lines of Hutchinson and Waters' target language needs, both necessities and wants (1987). In other words, the aim of the needs analysis should be to identify what the learners need to know in order to function 
effectively in target domains. Two questions arise at this point: 1 . In what domains do the learners need to use the target language? 2. In what form should the target needs within these domains be conceptualised (e.g., structures, lexis, communicative functions, situations, skills etc.)?

As far as the first question is concerned, the hypothesis was that Technical University students needed to use English in vocational, academic and everyday life domains. The needs survey confirmed the hypothesis and showed that both the vocational and the academic environment required these students to be able to use English. Furthermore, students expressed their subjective needs in terms of using the language in these domains as well as in everyday life. (I will return to these findings later when discussing the issue of conflicting needs.)

On the basis of the above results it became possible to identify the broad aims of the needs-based course: The aim of instruction is to develop the ability in the learners to engage, in a skilled way, in communication with members of the English speaking community. The instruction will concentrate on the domains where learners are and will be required to use their command of the language. The three domains are vocational, academic and everyday life.

As far as the second question is concerned, target needs were not defined in the form of linguistic items. On a practical level, it was taken into consideration that most participants of the survey were not familiar with concepts specific to the field of foreign language teaching and learning. Also, expressing needs in terms of linguistic elements would raise the expectation that the respondents devote time to the linguistic analysis of the target domains. Such an expectation is highly unrealistic.

At this point, it is possible to argue that the analysts themselves should investigate the target domains in order to carry out the linguistic analysis and base the syllabus design on the results. There are, however, a number of arguments which reject, on a theoretical level, syllabus content specification, and as a consequence needs specification, in the form of linguistic items. Thus, it is maintained that linguistic items do not possess the properties of language as a whole (Vygotsky 1986), they do not model language in its active state (Lantolf \& Appel 1994, McNeill 1986), and they do not represent the way language is acquired (Larsen-Freeman \& Long 1991:88-96, Widdowson 1990, Wilkins 1976). (It is beyond the scope of the present paper to investigate these issues any further here.)

36 The above statements formed part of the theoretical framework for the needs-based course design and, therefore, were relevant in terms of designing the needs-based syllabus. On the basis of these statements, it was possible to determine how to conceptualise language for teaching purposes, which in turn made it possible to decide in what form target language needs should be conceptualised.

For the purposes of target language teaching, language is viewed as a holistic system. It is conceptualised as action (i.e. when it is in use as opposed to looking at it as a static object) (McNeill 1986). As such, it forms part of a greater entity, activity. It means that language is always directed towards certain goals, it is driven by motives and determined by the context in which it takes place (for a discussion on the conceptualisation of language within Activity Theory see Lantolf \& Appel 1994; Wertsch 1979; Leont'ev 1981).

Target language needs were defined in accordance with the theoretical framework outlined above, where language is looked at as part of human activities. Since human activities are characterised by their context as well as the motives and goals of the 
participants it was not possible to predict and list every activity in which the use of English is possibly be needed by the students. What was possible, however, is to arrive at a list of real-life tasks which the students needed to be able to fulfil! By "task" I mean the description of what needs to be done as opposed to what is actually done (i.e., activity). In this sense, tasks are schematic in nature, and they come to life in the form of activities. Target language needs were investigated in the form of tasks within our needs survey (See Appendix 1 for the identified needs, in the form of tasks, of different target groups.)

\section{What to do with identified needs?}

It was mentioned in Section One that there are three possible ways of relating to identified needs. We can ignore them, interpret them or adopt them directly (Berwick 1989). As far as our needs based syllabus design is concerned, every attempt was made not to ignore learner needs. It was not possible, however, to include the identified needs directly into the syllabus. This is because our definition of target language needs for needs analysis purposes (i.e., tasks)was not identical with the unit of the proposed syllabus (for a definition see the subsequent paragraphs). Therefore, it was not possible to claim that the identified needs, arranged in a certain order, should form the contents of the syllabus.

While the English language needs of students were identified in terms of tasks it was stated that the aim of the proposed English language course was not simply to provide the learners with opportunities to fulfil tasks by carrying out activities. Rather, the aim was to develop the ability in the learners to engage, in a skilled way, in activities where interaction between the individual and the environment was carried out with the inclusion of the target language. Therefore, skills were proposed as the syllabus unit.

Within the theoretical framework for syllabus design skills were defined as a characteristic feature of human activities (such as language behaviour). In general, an activity is carried out in a skilled way if a sufficient amount of attention is available for its completion, the performer is capable of anticipating subsequent actions, the behaviour is not stereotyped, the operations involved are automated. Skills are made up of subskills which are in a very complex interdependent relationship with one another. The smooth integration of subskills is crucial from the point of view of skilful engagement in activities. Part of the subskills are target language specific in nature. There are also subskills involved which are not specific to the target language. Research findings suggest that, to a certain degree at least, the two types of subskills develop together rather than in entire separation (Clarke 1980).

Proposing skills as the unit of analysis made it necessary to interpret learner needs in order to develop the syllabus. This was done by analysing every identified task in terms of what skills the students needed to develop in order to carry them out. ${ }^{4}$ (See Appendix 2 for the complete list of skills.)

What follows is an example of a task analysed in terms of the skills that are required to participate in it (see table 1). 
Table 1. Example of a task: reading professional literature

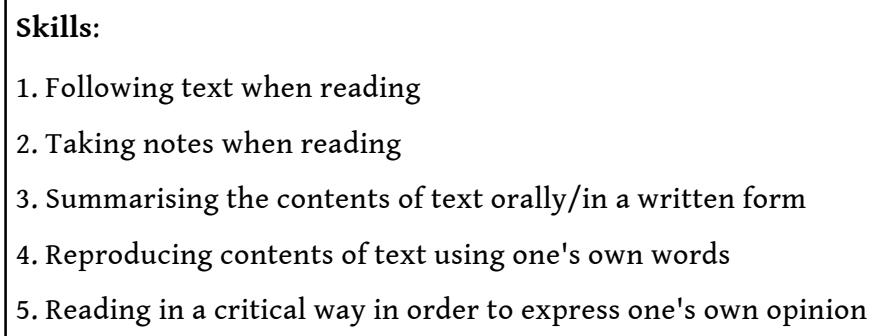

A further example is the task of attending training courses in English (see table 2).

Table 2. Example of a task: attending training courses in English

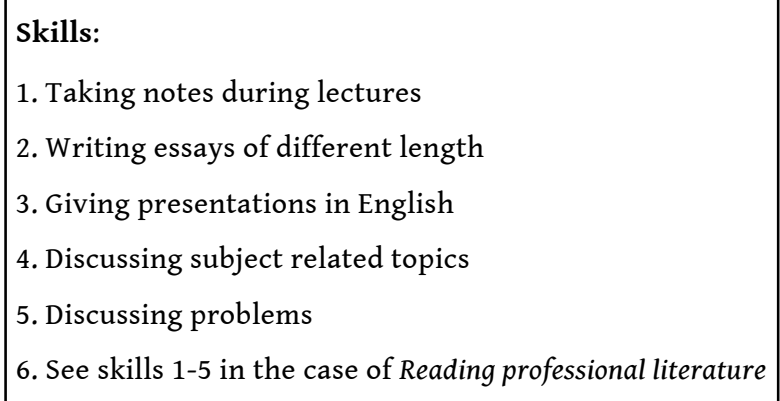

It can be seen from the above example that some of the skills were required in the case of both reading the literature and attending training courses in English. Indeed, skills overlapped in the case of most activities which were identified during the needs survey, This fact reduced the number of skills needed by the learners to be able to carry out activities in vocational, academic and everyday life domains. The list of identified skills formed the raw syllabus (i.e. without offering a sequencing of skills for teaching purposes) of the proposed needs-based course (see Appendix 3). It is beyond the purposes of the paper to discuss how subskills (both target language specific and non-target language specific) were dealt with within the broader framework of the needs-based course design.

\section{Conflicting needs}

It was stated in Section One, that it is possible that different target groups express different needs in terms of language learning, and that these needs may conflict. To a certain extent, this was the case with the needs of the four target groups participating in our survey. (This is one of the reasons why our hypothesis was confirmed.) As a consequence, it was essential to decide whose needs to give priority to when designing the course. In terms of syllabus design, it was decided to ignore EFL teachers' opinions. It was maintained that it was not the EFL teachers' role to determine the objectives of the language course. Rather, their role was to facilitate the achievement of these objectives. Priority was given to the needs expressed by company representatives and subject lecturers respectively. Target language needs expressed by the business community were regarded the most important on the basis of the needs analysis findings (see summary in 
Section Two). Academic needs were also regarded important because subject lecturers indicated that they required (or, in some cases, they would have liked to have been able to require) the students to use English for academic purposes ${ }^{5}$, students appeared motivated to use their command of the language for such purposes, and also because vocational and academic purposes of language use overlapped to a certain extent. Students' wants in terms of everyday life activities were also taken into consideration.

Taking into account the language needs of three target groups meant that the list of tasks in which students needed to be able to participate was quite long. As a consequence, the total number of skills identified on the basis of the activities was even longer. As shown in the previous subsection, however, the overlap between tasks in terms of skills reduced the number of candidates for syllabus items. Apart from the fact that reducing the number of skills made the proposed language course more manageable in terms of time, the overlap between tasks also indicated that needs do not only conflict but overlap as well. Thus, certain skills appeared to be useful for more than just one task and domain. For example, the skill 'providing and asking for personal information' proved useful in all three domains, both in speaking and writing.

\section{Limitations of the proposed syllabus}

There were three issues the syllabus design was not concerned with. One was the question of how to develop the identified skills in the learner. This is because it is maintained that it is the role of methodology to deal with this question. While a methodological framework was proposed within the research project it is beyond the purposes of the paper to describe it here.

Similarly, the syllabus design did not provide guidelines in terms of which syllabus items (i.e.,skills) to select for the purposes of developing an actual needs-based English language course for a given group of Technical University students. This is because our needs analysis was carried out on a large scale. As such, it did not aim to determine what Hutchinson and Waters (1987) call "lacks" (i.e., "the necessities the learner lacks", 55). I would argue that it is the role of a group-size needs analysis to determine what a group of learners know already and what they need to focus on in relation to the already identified target needs.

The third issue the syllabus design did not deal with relates to the sequencing of syllabus items. Again, I would suggest that decisions should be made at group-level in relation to the ordering of the selected skills. It is possible, however, to provide guidelines in terms of the sequencing of syllabus content on the basis of research findings into Second Language Acquisition (SLA). Since SLA research suggests that language development does not take place in a linear fashion (Laufner 1990; Patkowski 1990; Pienemann 1985; Sato 1990) immediate target-like mastery should not be expected and backsliding should also be recognised as a sign of language development. These findings suggest that skills should be addressed more than once during a language course. This calls for a cyclic rather than a linear ordering of the syllabus content.

Also, it is maintained that learners should be provided with a reasonable amount of exposure to new language so that they can observe it and form hypotheses before production is expected from them (Krashen 1982). In terms of the ordering of the syllabus 
items, it means that skills with a receptive focus should precede and serve as a basis for skills with a productive focus.

\section{BIBLIOGRAPHY}

Allen, W. \& N. Spada. 1983. "Designing a communicative syllabus in the People's Republic of China". In Jordan, R. (ed.), Case studies in ELT. London: Collins, 132-145.

Allwright, R. 1982. “Perceiving and pursuing learner's needs”. In Geddes, M. \& G. Sturtridge (eds.), Individualisation. Oxford: Modern English Publications, 24-31.

Berwick, R. 1989. "Needs assessment in language programming: from theory to practice". In Johnson, R. K. (ed.), The Second Language Curriculum. Cambridge: Cambridge University Press, 48-62.

Brindley, G. 1989. "The role of needs analysis in adult ESL programme design". In Johnson, R. K. (ed.), The Second Language Curriculum. Cambridge: Cambridge University Press, 63-78.

Clarke, M. A. 1980. “The short-circuit hypothesis”. Modern Language Journal 64, 203-209.

Coffey, B. 1984. “ESP - English for specific purposes”. Language Teaching 17/1, 2-16.

Crocker, T. 1981. "Scenes of endless science ESP and education". ELT Documents 112, 7-15.

Dubin, F. \& E. Olstain. 1986. Course Design. Cambridge: Cambridge University Press.

Holliday, A. 1994. "The house of TESEP and the communicative approach: the special needs of state English language education". ELT Journal 48/1, 3-11.

Hutchinson, T. \& A. Waters. 1987. English for Specific Purposes. Cambridge: Cambridge University Press.

Jacobson, W. H. 1986. "An assessment of the communication needs of non-native speakers of English in an undergraduate physics lab". English for Specific Purposes 5/ 2, 173-187.

Johns, T. \& A. Dudley-Evans. 1980. “An experiment in team-teaching of overseas postgraduate students of transportation and plant biology". ELT Documents 106, 6-23.

Jones, C. 1991. “An integrated model for ESP course design". English for Specific Purposes 10/3, 155-172.

Krashen, S. 1982. Principles and Practice in Second Language Acquisition. Oxford: Pergamon Press.

Lantolf, J.P. \& G. Appel.1994. Vygotskian Approaches to Second Language Acquisition. Cambridge: Cambridge University Press.

Larsen-Freeman, D. \& M.H. Long. 1991. An Introduction to Second Language Acquisition Research. London: Longman,.

Laufer, B. 1990. "Sequence and order in the development of L2 lexis: some evidence for lexical confusions". Applied Linguistics 11/3, 281-296.

Lawson, K. H. 1979. Philosophical Concepts and Values in Adult Education. Milton Keynes: Open University Press. 
Leont'ev, A. N. 1981. “The problem of activity in psychology”. In Wertsch, J. V. (ed.), The Concept of Activity in Soviet Psycholog. Armonk, NY: M.E. Sharpe, 37-71.

Littlewood, W. 1992. “Curriculum Design”. Review of English Language Teaching 2/1, 11-22.

Long, M. H. 1985. “A role for instruction in second language acquisition: Task-based language teaching”. In Hyltenstam, K. \& M. Pienemann (eds.), Modelling and Assessing Second Language Acquisition. Clevedon, England: Multilingual Matters, 77-99.

Long, M. H. \& Crookes, G. 1992. “Three approaches to task-based syllabus design”. Tesol Quarterly $26 / 1,27-56$.

Mackay, R. \& M. Bosquet. 1981. "LSP curriculum development - from policy to practice". In Mackay, R. \& J. Palmer (eds.), Languages for Specific Purposes. Rowley, MA: Newbury House, 1-28.

McDonough, J. 1984. ESP in Perspective. London: Collins.

McNeill, D. 1986. “Language viewed as action”. In Wertsch, J.V. (ed.), Culture, Communication and Cognition. Cambridge: Cambridge University Press, 258-270.

Munby, J. 1978. Communicative Syllabus Design. Cambridge: Cambridge University Press.

Patkowski, M. 1990. “Age and accent in second language: A reply to James Emil Flege”. Applied Linguistics 11/1, 73-89.

Pienemann, M. 1985. "Learnability and syllabus construction”. In Hyltenstam, K. \& M. Pienemann (eds), Modelling and Assessing Second Language Development. Multilingual Matters.

Porcher, L. 1983. "Reflections on language needs in the school”. In Richterich, R. (ed.), Case Studies in Identifying Language Needs. Strasbourg: Council of Europe/Oxford: Pergamon, 127-149.

Prabhu, N. S. 1987. Second language Pedagogy. Oxford: Oxford University Press.

Richterich, R. 1980 [1973]. “Definition of language needs and types of adults”. In Trim, J., R. Richterich, J. van Ek \& D. Wilkins (eds.), Systems Development in Adult Language Learning. Strasbourg: Council of Europe/Oxford: Pergamon.

Richterich, R. (ed.). 1983. Case Studies in Identifying Language Needs. Strasbourg: Council of Europe/ Oxford: Pergamon.

Robinson, P. 1991. ESP Today: A Practitioner's Guide, London: Prentice Hall International.

Sárdi, C. 1996. "Angol nyelvi szüksegletfelmeres a gyori Szechenyi Istvan M Foiskolan”

(Surveying learners' English language needs at Szechenyi Istvan Technical University, Gydr.). In Térségfejlesztés és Organikus Tarsadalom, Székesfehérvár: VEAB.

Sárdi, C. 1998. "English language needs of students in Hungarian Technical Universities". In Grundy, P. (ed.), IATEFL 1997 Brighton Conference Selection. Whistable, UK: IATEFL.

Sato, C. J. 1990. The Syntax of Conversation in Interlanguage Development. Tubingen: Gunter Narr.

Tarone, E. \& G. Yule. 1991. Focus on the Language Learner. Oxford: Oxford University Press.

Teemant, A., Z. Varga \& P. Heltai. 1993. "Hungary's Nationwide Needs Analysis of Vocationally-Oriented Foreign Language Learning". Budapest, Hungary: Ministry of Education and Culture, Ministry of Labour, United States Information Agency, Council of Europe Modern Languages Project Group,.

Vygotski, L. S. 1986. Language and Thought. Cambridge, MA: MIT Press.

Wertsch, J. V. (ed.). 1979. The Concept of Activity in Soviet Psychology. Armonk, NY: M.E. Sharpe. 
West, R. 1994. "Needs analysis in language teaching”. Language Teaching 27/1, 1-19.

Widdowson, H. G. 1981. “English for specific purposes: criteria for course design”. In Selinker, L., E. Tarone \& V. Hanzeli (eds.), English for Academic and Technical Purposes: Studies in Honour of Louis Trimble. Rowley, MA: Newbury House.

Widdowson, H. G. 1990. Aspects of Language Teaching. Oxford: Oxford University Press, 1990.

Wilkins, D. A. 1976. Notional Syllabuses. Oxford: Oxford University Press.

\section{NOTES}

1. This is one of the thirteen papers accepted for Seminar 16 (ESP: chaired by Pr. Maurizio Gotti) in the European Society for the Study of English Conference (ESSE-4) held in Debrecen (Hungary) in September 1997.

2. The justification of the research project is provided by the fact that the teaching of English as a Foreign Language in Hungarian Technical Universities is crucial both to the national economy and to individual students. In the past seven years Hungary (like other Central European countries) has undergone radical changes in politics, economy and society. One of the consequences of these changes is that there is a growing need for experts speaking foreign languages in the labour market. For Technical University students it means that they need to be able to speak at least one foreign language (very often English) for career purposes. Yet there is a reported gap between the vocational needs of students in Hungarian Technical Universities and the existing objectives and outcomes of their English language courses (Teemant et al. 1993). Particularly since the amount of formal instruction is relatively small, it is essential that EFL courses should be built around the real language needs of the students.

3. It is important to stress that providing an opportunity for content specification does not need to mean that processes are overlooked. Within a target language course, the syllabus can (and indeed, should) be designed in line with methodological considerations. In other words, it is possible to design the syllabus so that it is in line with up-to-date information concerning the nature of language learning. At the same time, it must be seen that the syllabus is not the only instrument that can ensure that learning processes are catered for. Within the framework of course design, a methodological framework needs to operate that provides guidelines, in concert with our knowledge on language learning processes, in terms of what should be done in the classroom. The syllabus, however, is nothing more than a "schematic" abstract entity (Widdowson 1990: 127), and its role is by no means to determine the methodology and the classroom activities of the course. It cannot be stressed enough, however, that content specification should be done so that it lends itself to the application of methodology that facilitates learning processes.

4. Two members of the business community and two subject lecturers were also involved in this working process in order to make sure that the analysis was sufficient.

5. It should be noted here, however, that subject lecturers did not seem fully aware of the fact that students could be required to use English for academic purposes more than they actually were. 


\section{ABSTRACTS}

The usefulness of needs analysis for course design has been widely accepted in the field of target language teaching and learning. However, despite the large amount of empirical research into needs analysis and theoretical work into course design there does not seem to emerge any systematic approach in terms of how to link the two areas. In other words, it is not clear how to translate needs analysis findings into course design procedures. The paper outlines an attempt to integrate into course design the results of a needs analysis which investigated the English language needs of Technical University students in Hungary in 1996. Special emphasis is given to syllabus design. The paper reports on work in progress: the syllabus design is part of a Ph.D project which is very near completion.

L'utilité d'une analyse des besoins pour la création d'un programme a été très largement reconnue dans le domaine de l'enseignement et l'apprentissage des langues pour des groupes cibles. Néanmoins, malgré la quantité de recherches empiriques sur l'analyse des besoins et les nombreuses études théoriques sur la création des programmes, aucune approche systématique reliant les deux domaines n'existe encore. Autrement dit, on ne sait pas encore traduire les conclusions d'une analyse des besoins en méthode de création des programmes. Nous décrivons l'intégration dans la création d'un programme des résultats d'une analyse des besoins en langue anglaise d'étudiants d'une université technique hongroise. Cet article représente des travaux en cours ; la création de ce programme fait partie d'un sujet de recherche de doctorat.

\section{INDEX}

Keywords: course design, needs analysis, syllabus

Mots-clés: analyse des besoins, création de cours, syllabus

\section{AUTHOR}

\section{CSILLA SÁRDI}

